\title{
Penggunaan Lingkungan Sekolah sebagai Laboratorium IPA untuk Meningkatkan Aktivitas dan Hasil Belajar Biologi Siswa Kelas VII MTs. Al-Islahussibyan Dopang Gunung Sari
}

\author{
Hayatun Nufus* \\ IKIP Mataram, Mataram, Indonesia \\ *Coresponding Author: hnufus03@gmail.com \\ Dikirim: 07-06-2021 ; Direvisi: 08-06-2021 ; Diterima: 08-06-2021
}

\begin{abstract}
Abstrak: Pembelajaran biologi di MTs. Al-islahussibyan Dopang Gunung Sari masih menggunakan pola pendekatan yang bersifat klasikal yaitu guru lebih mendominasi proses pembelajaran. Guru hanya menyampaikan materi dengan metode ceramah dan dan menjawab soal, sedangkan siswa hanya duduk, diam, mencatat dan mengerjakan soal. Penyajian materi seperti pola tersebut dapat menimbulkan gejala kejenuhan terhadap siswa, sehingga berpengaruh terhadap aktivitas dan hasil belajar siswa. Tujuan penelitian adalah untuk mengetahui implikasi penggunaan lingkungan sekolah sebagai laboratorium IPA dalam meningkatkan aktivitas dan hasil belajar biologi siswa di MTs. Al- Islahussibyan Dopang Gunung Sari Tahun Pelajaran 2010/2011. Jenis penelitian ini adalah Penelitian Tindakan Kelas (PTK) yang dilaksanakan dalam 2 siklus yang terdiri atas atas perencanaan, pelaksanaan, observasi dan refleksi. Jenis data yang digunakan dalam penelitian ini ada 2 yaitu: data kuantitatif dan kualitatif. Data kuantitatif berupa lembar observasi keterlaksanaan RPP, observasi kegiatan guru dan siswa dalam proses pembelajaran dan lembar angket aktivitas siswa, sedangkan data kuantitatif diperoleh dari hasil evaluasi tes hasil belajar siswa yang diberikan pada akhir setiap siklus untuk mendapatkan data mengenai hasil belajar siswa. Dari hasil penelitian menunjukan bahwa ada peningkatan aktivitas dalam belajar biologi dengan penggunaan lingkungan sekolah sebagai laboratorium IPA. Pada siklus I sebesar $75 \%$ dengan kategori tinggi dan meningkat pada siklus II menjadi $76 \%$ dengan kategori sangat tinggi. Peningkatan juga terlihat pada hasil belajar siswa, pada siklus I ketuntasan klasikal hasil belajar yang dicapai sebesar 70\% dan pada siklus II meningkat menjadi $85 \%$ dengan kategori tuntas. Jadi dapat disimpulkan bahwa penggunaan lingkungan sekolah sebagai laboratorium IPA dapat meningkatkan aktivitas dan hasil belajar biologi siswa Kelas VII MTs. Al-Islahussibyan Dopang Gunung Sari Tahun Pelajaran 2010/2011.
\end{abstract}

Kata Kunci: Lingkungan sekolah; laboratorium; aktivitas belajar; hasil belajar.

Abstract: Learning biology in MTs. Al-islahussibyan Dopang Gunung Sari still uses a classical approach, namely the teacher dominates the learning process. The teacher only conveys the material using the lecture method and and answers questions, while the students just sit, remain silent, take notes and work on the questions. Presentation of material such as this pattern can cause symptoms of boredom to students, so that it affects student activities and learning outcomes. The purpose of the study was to find out the implications of using the school environment as a science laboratory in increasing students' biology learning activities and outcomes in MTs. Al-Islahussibyan Dopang Gunung Sari for the 2010/2011 academic year. This type of research is Classroom Action Research (CAR) which is carried out in 2 cycles consisting of planning, implementation, observation and reflection. There are 2 types of data used in this study, namely: quantitative and qualitative data. Quantitative data are in the form of observation sheets for the implementation of lesson plans, observations of teacher and student activities in the learning process and questionnaires for student activities, while quantitative data are obtained from the results of the evaluation of student learning outcomes tests given at the end of each cycle to obtain data on student learning outcomes. The results of the study indicate that there is an increase in activity in learning biology by 
using the school environment as a science laboratory. In the first cycle it was $75 \%$ in the high category and increased in the second cycle to $76 \%$ in the very high category. The increase was also seen in student learning outcomes, in the first cycle of classical completeness the learning outcomes achieved were $70 \%$ and in the second cycle increased to $85 \%$ with the complete category. So it can be concluded that the use of the school environment as a science laboratory can increase the activity and learning outcomes of biology class VII MTs students. Al-Islahussibyan Dopang Gunung Sari Academic Year 2010/2011.

Keywords: School environment; laboratory; activities; learning outcomes.

\section{PENDAHULUAN}

Pendidikan sering diartikan sebagai usaha manusia untuk membina kepribadiannya sesuai dengan nilai-nilai di dalam masyarakat dan kebudayaan. Seperti pengertian yang diberikan oleh Langeveld yaitu pendidikan ialah setiap usaha, pengaruh, perlindungan dan bantuan yang diberikan kepada anak, tertuju kepada pendewasaan anak itu, atau lebih tepat membantu anak agar cukup cakap melaksanakan tugas hidupnya sendiri. Pengaruh itu datangnya dari orang dewasa atau yang diciptakan oleh orang dewasa seperti sekolah, buku, putaran hidup seharihari, dan sebagainya, serta diajukan kepada orang yang belum dewasa (Hasbullah, 2009).

Dalam pengertian yang luas, pendidikan merupakan sebuah proses dengan metode tertentu untuk memperoleh pengetahuan, pemahaman, dan cara bertingkah laku sesuai dengan kebutuhan (Dalyono, 2009). Menurut Udang-Undang No. 20 Tahun 2003 tentang Sistem Pendidikan Nasional, pendidikan adalah usaha sadar dan terencana untuk mewujudkan suasana belajar dan proses pembelajaran agar peserta didik secara aktif mengembangkan potensi dirinya untuk memiliki kekuatan spritual keagamaan, pengendalian diri, kecerdasan, ahlak mulia serta keterampilan yang diperlukan, masyarakat, bangsa dan negara (Hasbullah, 2009).

Dalam pembelajaran biologi guru diharapkan dapat menerapkan metode belajar yang tepat. Salah satu metode yang dapat digunakan adalah metode praktikum sebagai pendamping metode ceramah di kelas. Metode praktikum dilakukan dengan melaksanakan kegiatan praktikum sesuai dengan materi yang disampaikan. Metode ini akan menjadi lebih penting artinya apabila dikaitkan dengan aktivitas dan hasil belajar siswa, sebab dengan adanya kegiatan praktikum siswa dapat belajar menggunakan semua panca indera sehingga hal-hal yang bersifat abstrak dapat difaktakan (Roestiyah, 2008). Dengan demikian kegiatan praktikum diharapkan dapat menarik minat belajar siswa sehingga dapat meningkatkan aktivitas dan hasil belajar.

Kegiatan praktikum memungkinkan terjadinya interaksi antar siswa dengan siswa, siswa dengan guru, maupun siswa dengan lingkungan, membangkitkan motivasi belajar IPA, serta pembelajaran menjadi lebih bermakna dan efektif karena bersentuhan langsung dengan alam sekitar. Kegiatan praktikum secara tidak langsung memberikan kesadaran atau pemahaman tentang pentingnya lingkungan sebagai tempat mahluk hidup tinggal dan menggantungkan hidupnya (Faza, 1986). Kegiatan praktikum dalam pembelajaran biologi biasanya dilakukan di laboratorium. Laboratorium tidak hanya diartikan sebagai sebuah ruangan tempat melakukan percobaan tetapi alam terbuka/lingkungan seperti kebun sekolah, halaman sekolah, 
dan sebagainya dapat disebut sebagai laboratorium (Lubis, 1993). Laboratorium dapat berbentuk suatu ruangan yang tertutup, seperti: laboratorium di sekolahsekolah dan rumah kaca, maupun laboratorium sebagai ruangan terbuka seperti kebun sekolah dan lingkungan lain yang digunakan sebagai sumber belajar (Poewadarminta, 1982).

Berdasarkan hasil observasi, pembelajaran biologi di MTs. Al-Islahussibyan Dopang Gunung Sari masih menggunakan pola pendekatan yang bersifat klasikal yaitu guru lebih mendominasi proses pembelajaran. Guru hanya menyampaikan materi dengan metode ceramah dan menjawab soal, sedangkan siswa hanya duduk, diam, mencatat dan mengerjakan soal tersebut. Penyajian materi seperti pola tersebut dapat menimbulkan gejala kejenuhan terhadap siswa.

Melihat betapa pentingnya kegiatan praktikum sebagai pendamping metode ceramah dalam pembelajaran biologi maka di tiap-tiap sekolah sudah seharusnya melaksanakan kegiatan praktikum dengan mengacu pada kurikulum yang berlaku. Kegiatan praktikum di MTs. Al-Islahussibyan Dopang Gunung Sari belum dilakukan secara optimal. Hal ini terjadi karena peralatan laboratorium kurang memadai. Oleh karena itu penulis tertarik untuk menerapkan metode praktikum dengan memanfaatkan lingkungan sekolah, seperti halaman sekolah sebagai laboratorium IPA untuk meningkatkan aktivitas dan hasil belajar biologi siswa Kelas VII MTs. AlIslahussibyan Dopang Gunung Sari Tahun Pelajaran 2010/2011.

\section{METODE PENELITIAN}

\section{Jenis Penelitian}

Jenis penelitian yang dilakukan dalam penelitian ini adalah Penelitian Tindakan Kelas (PTK). Penelitian tindakan kelas merupakan penelitian yang dilakukan secara sistematis dan reflektif terhadap berbagai aksi atau tindakan guru di kelas dengan tujuan untuk memperbaiki kinerja guru sehingga hasil belajar siswa jadi meningkat (Arikunto, 2010). Metode penelitian tindakan kelas menekankan pada suatu kajian yang benar-benar dari situasi alamiah kelas sehingga mampu memperbaiki dan meningkatkan kualitas hasil belajar mengajar (Aqib, 2006).

\section{Pendekatan Penelitian}

Pendekatan adalah suatu cara yang digunakan oleh peneliti dalam suatu urutan penelitian yang akan dilakukan (Nazir, 2005). Dalam penelitian ini pendekatan yang digunakan terbagi dalam dua jenis yaitu pendekatan kualitatif dan pendekatan kuantitatif. Pendekatan kualitatif adalah pendekatan penilaian yang dilakukan dalam bentuk kalimat, kata atau gambaran baru ataupun menguatkan suatu gambaran yang ada (Haryono, 1998). Pendekatan kualitatif digunakan untuk mendapatkan data mengenai aktivitas siswa melalui angket (Quesioner). Pendekatan kuantitatif merupakan pendekatan penelitian yang memperoleh data dalam bentuk jumlah. untuk menjelaskan suatu kejelasan dari angka-angka atau membandingkan dari beberapa gambaran sehingga memperoleh gambaran baru, kemudian dijelaskan kembali dalam bentuk kalimat (Arikunto, 2010). Pendekatan ini digunakan untuk mendapatkan data mengenai hasil belajar siswa.

\section{Variabel Penelitian}

Variabel bebas adalah variabel yang mempengaruhi atau menjadi sebab perubahan atau timbulnya variabel terikat, tetapi tidak dapat dipengaruhi oleh 
variabel lain (Sugiono, 2009). Variabel bebas dalam penelitian ini adalah penggunaan lingkungan sekolah sebagai laboratorium IPA. Variabel terikat adalah variabel yang dipengaruhi atau yang menjadi akibat karena adanya variabel bebas (Sugiono, 2009). Variabel terikat dalam penelitian ini adalah aktivitas dan hasil belajar siswa dalam pembelajaran biologi.

\section{Tempat dan Waktu Penelitian}

Penelitian ini dilaksanakan di MTs. Al-Islahussibiyan Dopang Gunung Sari Lombok Barat. Penelitian dilaksanakan pada Semester Genap Tahun Pelajaran 2010/2011.

\section{Rancangan Penelitian}

Rancangan penelitian adalah rancangan yang dibuat oleh peneliti sebagai ancang-ancang kegiatan yang akan dilaksanakan (Arikunto, 2010). Penelitian ini dilaksanakan dengan penelitian tindakan kelas, menggunakan rancangan penelitian yang terdiri atas dua siklus. Setiap siklus terdiri dari 4 tahapan yaitu, perencanaan (planning), pelaksanaan tindakan (acthing), observasi (observation) dan refleksi (reflection).

Perencanaan yang dilakukan oleh penulis harus sesuai dengan apa yang direncanakan sebelumnya sehingga proses belajar mengajar dapat berjalan dengan baik dan sesuai dengan prosedur. Langkah-langkah yang dilakukan pada tahap ini antara lain: membuat skenario pembelajaran atau program pengajaran (RPP) , membuat lembar kerja siswa (LKS) dan tes berupa tes pilihan ganda, membuat instrumen tes hasil belajar (soal), dan Pelaksanaan Aksi atau Tindakan (Acthing). Dalam tahapan tindakan, dilakukan penerapan apa yang sudah dirumuskan dalam rancangan pembelajaran sesuai dengan skenario dan rencana pembelajaran yang telah disusun.

Kegiatan observasi dilakukan secara kontinyu setiap kali pembelajaran berlangsung sdalam pelaksanaan tindakan dengan mengamati kegiatan guru dan aktivitas siswa. Kemudian hasil yang diperoleh dari observasi dan evaluasi belajar siswa disimpulkan secara analisis, sehingga dari hasil tersebut peneliti dapat merefleksikan diri dengan melihat data observasi, yaitu identifikasi kekurangan, analisis sebab kekurangan dan menentukan perbaikan pada siklus berikutnya.

\section{Teknik Pengumpulan Data}

Teknik pengumpulan data adalah cara yang digunakan peneliti dalam mengumpulkan data penelitiannya (Arikunto, 2002). Teknik pengambilan data yang digunakan dalam penelitian ini adalah Observasi Aktivitas Guru, diamana metode pengumpulan data yang menggunakan pengamatan terhadap objek penelitian. Observasi dapat dilaksanakan secara langsung (Riyanto, 2006). Observasi yang dilakukan untuk mengamati aktivitas keterlaksanaan RPP. Aktivitas yang dimaksud adalah terlaksananya proses pembelajaran sesuai dengan skenario pembelajaran yang telah disusun. Kemudian angket (Quesioner) Aktivitas siswa, yaitu teknik pengumpulan data dengan cara mengirimkan suatu daftar pertanyaan kepada responden untuk diisi (Sukandarrumidi, 2004). Angket aktivitas siswa dalam penelitian ini yaitu siswa langsung menjawab sejumlah pernyataan yang diberikan oleh guru. Instrumen selanjutnya adalah Tes Hasil Belajar pertanyaan yang harus dijawab, pernyataan-pernyataan, atau tugas-tugas yang harus dilakukan oleh orang yang dites dengan tujuan untuk mengukur suatu aspek (perilaku) tertentu dari orang 
yang dites (Tim Puspendik, 2008). Tes yang diberikan dalam penelitian ini mengetahui penguasaan atau hasil belajar siswa terhadap materi pelajaran yang telah diberikan selama proses belajar-mengajar dengan penggunaan lingkungan sekolah sebagai laboraturium IPA.

\section{Instrumen Penelitian}

\section{Instrumen Aktivitas Guru}

Instrumen yang digunakan dalam penelitian ini berupa skenario pembelajaran atau Rencana Pelaksanaan Pembelajaran (RPP) dan lembar observasi. Lembar observasi adalah alat yang digunakan untuk mencatat hasil observasi. RPP adalah rencana yang menggambarkan prosedur dan pengorganisasian pembelajaran untuk mencapai satu kompetensi dasar yang ditetapkan dalam Standar Isi dan dijabarkan dalam silabus (Anonim, 2005). Silabus dan RPP yang disusun dikembangkan dari SK (Standar Kompetensi) ke-6 yaitu Memahami Keanekaragaman Mahluk Hidup, dari SK ke-6 ini yang digunakan untuk penyelidikan adalah KD (Kompetensi Dasar) ke-6.1 yaitu Mengidentifikasi Ciri-ciri Mahluk Hidup dan KD ke-6.2 yaitu Mengklasifikasikan Mahluk Hidup Berdasarkan Ciri-ciri yang Dimiliki.

\section{Instrumen Aktivitas siswa}

Angket aktivitas siswa (Quesioner) adalah sederetan pertanyaan yang telah tersusun dari yang umum mengarah pada yang khusus untuk diberikan kepada responden atau informasi yang merupakan pertanyaan (Nasution, 2001). Aktivitas siswa dalam penelitian ini yaitu siswa menjawab sejumlah pernyataan atau soal dalam bentuk angket yang diberikan oleh guru. Tes pilihan ganda merupakan tes dengan menjawab soal yang jawabannya harus dipilih dari beberapa kemungkinan jawaban yang telah disediakan (Tim puspendik, 2008).

Instrumen aktivitas siswa terhadap penggunaan lingkungan sekolah dapat dianalisis secara kualitatif dengan langkah-langkah :
a. Skor 5 diberikan jika semua deskriptor nampak : Sangat Aktif
b. Skor 4 diberikan jika 3 deskriptor nampak : Aktif
c. Skor 3 diberkan jika 2 deskriptor nampak : Cukup Aktif
d. Skor 2 diberikan jika 1 deskriptor nampak : Kurang Aktif
e. Skor 1 diberikan jika tidak ada deskriptor nampak : Sangat Tidak
Aktif

\section{IInstrumen Tes Hasil Belajar}

Tes hasil belajar merupakan alat yang digunakan untuk mengetahui sejauh mana keberhasilan siswa dalm proses pembelajaran sesuai dengan skenario yang telah dibuat seperti RPP (Rencana Pelaksaan Pembelajaran) dan silabus. Silabus merupakan rencana pembelajaran pada suatu atau kelompok mata pelajaran tertentu yang mencakup standar kompetensi, kompetensi dasar, materi pokok, indikator, penilaian, alokasi waktu, dan sumber atau bahan belajar.

Tes hasil belajar mengisyaratkan hasil belajar sebagai program atau objek yang menjadi sasaran penilaian. Hasil belajar sebagai objek penilaian pada hakikatnya menilai penguasaan siswa terhadap tujuan-tujuan instruksional. Tes hasil belajar dalam penelitian ini dalam bentuk soal pilihan ganda sebanyak 10 butir soal.

\section{Teknik Analisis Data \\ Analisis Aktivitas Guru}

Menentukan persentase aktivitas guru dengan rumus sebagai berikut : 
$\%$ Keterlaksanaan $=\frac{A}{B} x 100 \%$

Keterangan:

terlaksana

$$
\text { A = Langkah aktivitas/pembelajaran yang }
$$

yangdirencanakan

$\mathrm{B}=$ Seluruh langkah aktivitas/pembelajaran

Tabel 1. Konversi Persentase Keterlaksanaan RPP dalam Kegiatan Belajar Mengajar.

\begin{tabular}{|c|c|c|}
\hline Skala perolehan & Persentase $(\%)$ & Kategori \\
\hline $29-35$ & $81-100$ & Sangat baik \\
\hline $22-28$ & $61-80$ & Baik \\
\hline $15-21$ & $41-60$ & Cukup baik \\
\hline $8-14$ & $21-40$ & Tidak baik \\
\hline $0-0$ & $0-20$ & Sangat tidak baik \\
\hline
\end{tabular}

(Diadaptasi dari Arikunto, 2006) Siklus I

Analisis Hasil Observasi Aktivitas Guru dalam Keterlaksanaan Pembelajaran

A $=$ Langkah aktivitas/pembelajaran yang terlaksana $=6$

$\mathrm{B}=$ Seluruh langkah aktivitas/pembelajaran yang direncanakan

$$
=10
$$

$$
\begin{aligned}
\% \text { keterlaksanaan } & =\frac{A}{B} \times 100 \% \\
& =\frac{6}{10} \times 100 \% \\
& =60 \%
\end{aligned}
$$

Jadi, aktivitas guru dalam keterlaksanaan pembelajaran siklus I masuk dalam kategori cukup baik. Analisis Hasil Observasi Aktivitas Guru dalam Keterlaksanaan Pembelajaran Siklus II

$$
\begin{aligned}
& \mathrm{A}=\text { Langkah aktivitas/pembelajaran yang terlaksana }=9 \\
& \mathrm{~B}=\text { Seluruh langkah aktivitas/pembelajaran yang direncanakan= }
\end{aligned}
$$
10

$$
\begin{aligned}
\text { Persentase keterlaksanaan } & =\frac{A}{B} \times 100 \% \\
& =\frac{9}{10} \times 100 \% \\
& =90 \%
\end{aligned}
$$

Jadi aktivitas guru dalam keterlaksanaan pembelajaran siklus II masuk dalam kategori sangat baik.

\section{Analisis Aktivitas Siswa}

Data yang dipakai dalam aktivitas siswa disini adalah data kualitatif yakni sebagai berikut :

$$
\text { Aktivitas }=\frac{\text { jumlahskorsiswa }}{\text { jumlahskomaksimal }} \times 100 \%
$$




\section{Data Tes Hasil Belajar}

Setelah memperoleh data tes hasil belajar, maka data tersebut dianalisis dengan mencari ketuntasan belajar dan daya serap, kemudian dianalisis secara kualitatif. Setiap siswa dalam proses belajar dikatakan tuntas terhadap materi pelajaran yang diberikan apabila memperoleh nilai $\geq 60$.

$$
\begin{aligned}
K K= & \frac{Y}{Z} \times 100 \% \\
& \text { Keterangan : } \\
\mathrm{K} & =\text { Ketuntasan klasikal } \\
\mathrm{Y} & =\text { Jumlah siswa yang mencapai tuntas } \\
\mathrm{Z} & =\text { Jumlah keseluruhan siswa yang mengikuti tes } \\
& \text { (Sudjana, 2004) }
\end{aligned}
$$

Sesuai dengan petunjuk teknik penilaian kelas dapat dikatakan tuntas secara klasikal apabila mencapai 85\% dari jumlah siswa yang memperoleh nilai (Nasution, 2003). Analisis Data

\section{HASIL PENELITIAN}

Hasil penelitian ini terdiri dari dua data yaitu data kualitatif dan data kuantitatif. Data kualitatif yaitu data tentang keterlaksanaan pembelajaran hasil observasi penelitian tindakan kelas, hasil observasi aktivitas siswa dan hasil observasi kegiatan guru selama proses pembelajaran. Sedangkan data kuantitatif yaitu data hasil tes belajar dan ketuntasan belajar siswa sesuai dengan jenis penelitian yaitu penelitian tindakan kelas (PTK). PTK dilakukan sebanyak dua siklus dengan tindakan berulang-ulang dan masing-masing siklus terdiri dari dua kali pertemuan.

Uji coba validitas dan realibilitas tes evaluasi hasil belajar dilakukan pada siswa kelas VII dengan jumlah siswa 20 orang. Dari 10 butir soal pilihan ganda yang diuji cobakan kepada siswa pada siklus I diperoleh 9 butir soal yang valid dan 1 butir soal yang tidak valid, sedangkan pada siklus II diperoleh 10 butir soal yang valid. Sehingga dapat ditentukan validitas indikator soal dikatakan valid jika Mp-hitung $\geq$ r-tabel, dari hasil perhitungan didapatkan nilai validitas untuk r-hitung siklus I 0,212 dan nilai reliabilitas $-1,812$, sedangkan pada siklus II nilai validitas untuk r-hitung sebesar 0,3179 dan nilai reliabiltas -1,242. Karena hasil perhitungan r-hitung lebih besar dari r-tabel maka tes evaluasi siswa dikatakan valid yang reliabel, sehingga dapat dijadikan sebagai instrumen penelitian. Perincian pelaksanaan dan hasil yang diperoleh diuraikan sebagai berikut.

\section{Hasil Observasi Aktivitas Guru dalam Keterlaksanaan Pembelajaran}

Hasil observasi keterlaksanaan pembelajaran dinyatakan dalam persentase. Hasil keterlaksanaan pembelajaran ini menggambarkan tentang tingkat ketercapaian rencana langkah pembelajaran pada saat kegiatan belajar mengajar sesuai dengan pelaksanaan pembelajaran. Hasil observasi analisis keterlaksanaan pembelajaran dapat dilihat pada tabel berikut: 
Tabel 2. Data Hasil Aktivitas Guru dalam Keterlaksanaan Proses

Belajar Mengajar Siswa Kelas VII. A MTs. Al-

Islahussibyan Dopang Gunungsari Tahun Pelajaran

2010/2011

\begin{tabular}{|c|c|c|c|c|}
\hline Siklus & $\begin{array}{c}\text { Jumlah } \\
\text { pertemuan }\end{array}$ & $\begin{array}{l}\text { Jumlah langkah } \\
\text { pembelajaran }\end{array}$ & \multicolumn{2}{|c|}{$\begin{array}{c}\text { Jumlah langkah pembelajaran yang } \\
\text { terlaksana }\end{array}$} \\
\cline { 3 - 5 } & & Jumlah & Persentase \\
\hline I & Pertemuan I & 10 & 6 & $60 \%$ \\
& Pertemuan II & 10 & 6 & $60 \%$ \\
\hline II & Pertemuan 1 & 10 & 9 & $90 \%$ \\
& Pertemuan II & 10 & 9 & $90 \%$ \\
\hline
\end{tabular}

Dilihat dari tabel di atas terjadi peningkatan aktivitas guru dalam keterlaksanaan RPP. Pada siklus I persentase keterlaksanaan pembelajaran sebesar $60 \%$ dengan kategori baik, dan persentase tersebut mengalami peningkatan menjadi 90\% dengan kategori sangat baik. Hal ini terjadi karena sudah dilakukan perbaikanperbaikan pada siklus II.

\section{Data Hasil Angket Aktivitas Siswa}

Dari hasil analisis data diperoleh data mengenai minat belajar siswa pada siklus I dan II terlihat pada Table 3.

Tabel 3. Data Hasil Angket Aktivitas Siswa Kelas VII MTs. Al Islahussibyan Dopang Gunungsari Tahun Pelajaran 2010/2011.

\begin{tabular}{|c|c|c|c|}
\hline No & Siklus & Persentase Minat Belajar & Kategori \\
\hline 1 & I & $75 \%$ & Tinggi \\
2 & II & $76 \%$ & Sangat tinggi \\
\hline
\end{tabular}

Dari Tabel 3 di atas nilai rata-rata minat belajar siswa dengan penggunaan lingkungan sekolah sebagai laboratorium IPA pada siklus I dengan persentase $75 \%$ tergolong tinggi, selanjutnya pada siklus II dengan persentase $76 \%$ dan tergolong sangat tinggi. Hal ini menunjukkan bahwa minat belajar siswa meningkat pada tiap siklusnya

\section{Data Evaluasi Hasil Belajar Siswa}

Setelah dilakukan proses pembelajaran pada tiap siklusnya, maka setiap siswa diberikan tes. Tes dilakukan pada setiap akhir siklus dengan tujuan untuk mengetahui hasil belajar siswa. Data hasil evaluasi siswa dapat dilihat pada Tabel 4.

Tabel 4. Data Hasil Evaluasi Belajar Siswa Kelas VII. MTs.

Al-Islahussibyan Dopang Gunungsari Tahun

Pelajaran 2010/2011.

\begin{tabular}{|c|c|c|c|c|}
\hline \multirow{2}{*}{ Siklus } & \multirow{2}{*}{ Jumlah Siswa } & \multicolumn{2}{|c|}{ Siswa Tuntas } & \multirow{2}{*}{$\begin{array}{l}\text { Kategori Ketuntasan } \\
\text { Klasikal }\end{array}$} \\
\cline { 3 - 4 } & & Jumlah & Persentase & Tidak Tuntas \\
\hline I & 20 & 14 & $70 \%$ & Tuntas \\
\hline II & 20 & 17 & $85 \%$ & \\
\hline
\end{tabular}

Tabel tersebut menunjukkan bahwa hasil belajar siswa pada setiap siklus terjadi peningkatan dari $70 \%$ sampai $85 \%$. Pada siklus I hasil belajar siswa belum 
dikatakan tuntas secara klasikal karena belum memenuhi standar ketuntasan yang telah ditetapkan. Hal ini disebabkan karena pada siklus I banyak siswa yang tidak tuntas secara individu, kemudian pada siklus II dilakukan perbaikan-perbaikan dari kekurangan pada siklus 1 sehingga terjadi peningkatan ketuntasan secara sebesar $85 \%$. Persentase ketuntasan belajar tersebut sudah memenuhi standar ketuntasan, artinya pembelajaran biologi dengan penggunaan lingkungan sekolah sebagai laboratorium IPA bisa meningkatkan hasil belajar biologi siswa.

\section{PEMBAHASAN}

Penelitian ini dilaksanakan sesuai dengan prosedur PTK yang telah ditetapkan yakni diawali dengan perencanaan, pelaksanaan tindakan, observasi dan evaluasi sampai dengan tahap refleksi. Tahap perencanaan siklus I maupun siklus II sama yaitu menyiapkan rencana pelaksanaan pembelajaran, lembar observasi untuk mencatat kegiatan guru, angket untuk melihat sejauh mana minat siswa, menyusun soal evaluasi dan analis data.

Pada proses pembelajaran siklus I skenario pembelajaran belum terlaksana secara maksimal. Hal ini terlihat dari hasil analisis keterlaksanaan pembelajaran pada siklus I menunjukkan persentase sebesar $60 \%$ dan mengalami peningkatan pada siklus II sebesar 90\%. Perbedaan hasil persentase pada siklus I dan II disebabkan karena pada siklus I rencana kegiatan pembelajaran yang sudah disusun belum berjalan dengan baik, siswanya masih belum bisa terkontrol secara maksimal sehingga rencana pembelajaran yang sudah disusun tidak bisa berjalan dengan baik. Pada siklus II hampir semua rencana kegiatan pembelajaran berjalan dengan maksimal karena guru sudah mampu menciptakan suasana belajar mengajar yang kondusif.

Guru bersama peneliti melaksanakan refleksi terhadap proses belajar mengajar yang dilaksanakan pada siklus I, kekurangan yang terjadi pada siklus I tersebut dilakukan perbaikan pada siklus II. Dari hasil refleksi, dapat diketahui kekurangankekurangan yang menyebabkan data aktivitas dan hasil belajar belum maksimal, kekurangan tersebut disebabkan karena dalam proses pembelajaran peneliti yang sekaligus bertindak sebagai pendidik belum melaksanakan skenario pembelajaran secara maksimal. Beberapa kelemahan yang muncul pada siklus I diantaranya, (1) setiap awal pembelajaran siswa kelihatan tidak siap untuk mengikuti proses belajar mengajar; (2) siswa belum mengetahui apa manfaat dari belajar dengan memanfaatkan lingkungan sekolah sebagai laboratorium IPA; (3) ada beberapa pertanyaan siswa yang tidak langsung dijawab peneliti; (4) diakhir pembelajaran masih ada beberapa siswa yang terlihat belum paham terhadap materi yang sudah dijelaskan; (5) siswanya belum bisa terkontrol secara maksimal.

Dari permasalahan tersebut dilakukan perbaikan pada siklus II, yaitu pendidik harus menyusun kerangka penyelesaian terkait dengan masalah yang muncul pada siklus I sebagai brikut; (1) peneliti harus memberikan motivasi setiap awal pembelajaran agar siswa lebih aktif dalam melaksanakan pembelajaran; (2) sebaiknya peneliti menjelaskan kembali apa manfaat belajar dengan penggunaan lingkungan sekolah sebagai laboratorium IPA; (3) peneliti harus memiliki keterampilan dalam menjawab dan menanggapi pertanyaan siswa; (4) peneliti harus meninjau kembali materi yang sudah disampaikan; (5) peneliti juga harus menguasai materi yang akan diajarkan kepada siswa; (6) sebaiknya guru pamong tetap 
mengikuti kegiatan proses belajar mengajar agar siswa bisa terkontrol secara maksimal.

Setelah diadakan perbaikan pada siklus II terjadi peningkatan serta perubahan ke arah yang lebih baik. Ini ditunjukan dari hasil observasi aktivitas siswa dari kategori tinggi menjadi sangat tinggi. Hasil analisis dari perolehan nilai persentase angket aktivitas belajar siswa pada siklus I sebesar 75\% termasuk dalam kategori tinggi dan pada siklus II persentase angket aktivitas siswa meningkat sebesar $76 \%$ yang termasuk dalam kategori sangat tinggi. Meningkatnya aktivitas belajar siswa pada siklus II yang terlihat dari hasil angket menunjukkan bahwa penggunaaan lingkungan sekolah sebagai laboratorium IPA dapat meningkatkan aktivitas dan hasil belajar siswa dalam pembelajaran biologi.

Selain hasil observasi aktivitas guru dan siswa, pada hasil belajar biologi siswa juga mengalami peningkatan. Ini ditunjukan dari hasil evaluasi belajar siswa siklus 1 mencapai ketuntasan klasikal sebesar 70\%, sehingga belum dikatakan tuntas karena belum mencapai standar ketuntasan yang telah ditentukan. Hal ini disebabkan karena siswa belum terbiasa belajar dengan menggunakan metode praktikum dengan memanfaatkan lingkungan sekolah. Pada siklus II ketuntasan klasikalnya mencapai $85 \%$, nilai ini meningkat dari siklus I artinya pembelajaran sudah dikatakan tuntas secara klasikal dari standar yang ditetapkan dalam kurikulum sebesar $85 \%$.

Karena hasil penelitian ini telah mencapai indikator keberhasilan, yaitu aktivitas guru dalam mengajar dan aktivitas siswa dalam belajar dalam kategori sangat tinggi, serta ketuntasan klasikal hasil belajar siswa $\geq 85 \%$, maka penelitian ini dihentikan. Dengan alasan bahwa hasil penelitian ini telah mencapai indikator keberhasilan.

Kinerja guru dalam proses belajar mengajar sangat mempengaruhi aktivitas dan hasil belajar siswa. Meningkatnya kinerja guru dalam proses belajar mengajar, secara langsung akan dapat meningkatkan aktivitas an hasil belajar siswa.

Penerapan pembelajaran dengan penggunaan lingkungan sekolah sebagai laboratorium IPA dalam proses belajar mengajar sangat membantu guru dalam meningkatkan aktivitas dan hasil belajar siswa. Menurut Ibrahim (2003), aktivitas adalah kegiatan yang dilakukan oleh siswa dalam kegiatan belajar. Aktivitas belajar siswa berbeda antara satu sama lain. Hal ini dipengaruhi oleh penggunaan metode dan pendekatan belajar. Ketidaksamaan aktivitas siswa itu melahirkan kadar aktivitas yang bergerak dari aktivitas belajar rendah sampai pada aktivitas belajar yang tinggi (Djamarah, 1997). Meningkatnya aktivitas siswa tentunya sangat berpengaruh terhadap hasil belajar. Hasil belajar adalah kemampuan yang diperoleh anak dari suatu interaksi dalam proses pembelajaran (Djamarah, 2006). Siswa yang sudah memiliki aktivitas yang tinggi dalam belajar menunjukan siswa tersebut memiliki minat atau kemauan belajar yang tinggi, sehingga siswa tersebut juga dapat dengan mudah memperoleh hasil belajar yang baik. Sesuai dengan hasil penelitian, semakin tinggi aktivitas siswa maka akan semakin tinggi hasil belajar yang didapat.

\section{KESIMPULAN}

Berdasarkan hasil Penelitian Tindakan Kelas (PTK) yang telah dilaksanakan melalui beberapa tindakan dari siklus I dan siklus II dapat disimpulkan bahwa penggunaan lingkungan sekolah sebagai laboratorium IPA dapat meningkatkan aktivitas dan hasil belajar biologi siswa. Secara khusus penelitian ini dapat 
disimpulkan bahwa penggunaan lingkungan sekolah sebagai laboratorium IPA efektif untuk meningkatkan aktivitas belajar siswa Kelas VII MTs. Al-Islahussibyan Dopang Gunungsari Tahun Pelajaran 2010/2011. Hal ini dilihat dengan adanya peningkatan aktivitas belajar siswa di tiap siklus dimana pada siklus I persentase 75\% dengan kategori tinggi, meningkat menjadi $76 \%$ pada siklus II dengan kategori sangat tinggi. Penggunaan lingkungan sekolah sebagai laboratorium IPA efektif untuk meningkatkan hasil belajar siswa Kelas VII MTs. Al- Islahussibyan Dopang Gunungsari Tahun Pelajaran 2010/2011. Peningkatan ini dapat dilihat dari perolehan persentase ketuntasan belajar secara klasikal pada siklus I sebesar $70 \%$ dan pada siklus II sebesar $85 \%$ dikatakan tuntas secara klasikal.

Berdasarkan kesimpulan yang telah diuraikan di atas, disarankan bagi peneliti yang ingin melakukan penelitian dengan memanfaatkan lingkungan sekolah sebagai laboratorium IPA bisa menerapkan metode tersebut pada materi biologi dengan pokok bahasan yang berbeda dan tentunya disesuaikan dengan kondisi sekolah tempat melakukan penelitian.

\section{DAFTAR PUSTAKA}

Abdullah, T. 2010. Pengertian Lingkungan. http://Adullah,T.mastegar.blogspot. com/html. Diakses Tanggal 24 Desember pukul 15.00 WITA.

Afand. Pengertian Lingkungan. http://Afand.Cybermq.Com/post/. Diakses Tanggal 10 Desember pukul 13.00 WITA.

Anonim. 2009 Pengertian-Hasil-Belajar. http://technology.Wordpress.Com. Diakses Tanggal 15 Desember Pukul 17.00 WITA.

Anonim. 2008. Pengertian Fungsi dan Jenis Lingkungan Pendidikan. http:// Fatamorgana.Wordpress.com. Diakses tanggal 28 desember pukul 10.00 WITA.

Anonim. 2010. Pengertian lingkungan. http://mastegar.blogspot.com/html. Diakses Tanggal 13 Desember 2010 pukul 14.00 WITA.

Arikunto, Suharsimi. 2001. Prosedur Penelitian Suatu Pendekatan Praktik. Jakarta: Rineka Cipta.

Aqib, Z. 2006. Penelitian Tindakan Kelas. Bandung: CV. Yrama Widya.

Aqib, Z. 2002. Interaksi Belajar Mengajar. Departemen Pendidikan Nasional.

Dalyono. 2009. Psikologi Pendidikan. Jakarta: Rineka cipta.

Dhany. 2009. Kurikulum Tingkat Satuan. http://www.dhany.co.cc/html. Diakses Tanggal 29 Desember 2010 pukul 11.00 WITA.

Djamarah, Zain. 1996. Strategi Belajar Mengajar. Jakarta: PT. Rineka Cipta.

Haryono, 1998. Metodelogi Penelitian Penididikan. Bandung: Pustaka Setia.

Hasan, S. 2010. Profosal. http://www.Kd-sumedang.upi.edu/berkas/profosal/pdf. Diakses Tanggal 13 Desember 2010 pukul 14.00 WITA.

Hasbullah. 2001. Dasar-Dasar Ilmu Pendidikan. Jakarta: PT Raja Grafindo Persada. Ibrahim, R., Syaodis, N. 2003. Perencanaan Pengajaran. Jakarta: Rineka Cipta. 
Kardi, S. 2002. Strategi Motivasi ARCS. Departemen Pendidikan Nasional. Surabaya: Universitas Surabaya.

Martika. 2008. Penerapan Pembelajaran Langsung Dengan Menggunakan Media Charta Untuk Meningkatkan Aktivitas dan Prestasi Belajar Siswa Kelas V111 MTs Rahmatullah Al- Hasan Kekait Gunung Sari Tahun Pelajaran 2008/2009. Skripsi. Mataram: Ikip Mataram.

Nasution. 2010. Berbagai Pendekatan Dalam Proses Belajar dan Mengajar. Jakarta: PT Bumi Aksara.

Nasution, 2001. Metode Research. Jakarta: Bumi Aksara.

Nazir, M. 2005. Metode Penelitian. Bogor: PT. Ghalia Indonesia.

Purwanto. N. 2004. Psikologi Pendidikan. Bandung: PT. Remaja Rosdakarya Offset.

Reksoatmodjo, Tedjo. 2007. Statistika Untuk Psikologi dan Pendidikan.Bandung: Refika Aditama.

Rifai, A. 2009. Psikologi Pendidikan. Semarang: Unnes press.

Roestiyah. 2008. Strategi Belajar Mengajar. Jakarta: Rineka Cipta.

Rusdianti. 2008. Pemanfaatan Lingkungan Sekolah Sebagai Laboraturium IPA untuk Meningkatkan Keterampilan Proses Observasi dan Ketuntasan Belajar Siswa Pada Bidang Studi Biologi Pada Pokok Bahasan Ekosistem Siswa Kelas V11 MTs Hidayatullah Ampenan Tahun Pelajaran 2008/2009. Mataram: Skripsi Ikip Mataram.

Sudjana, N. 2005. Penilaian Hasil Proses Belajar Mengajar. Bandung: PT Remaja Rosdakarya Bandung.

Sugiono. 2009. Pengantar Evaluasi Pendidikan. Jakarta: PT.Raja Grafindo Persada

Sukandarrumidi. 2004. Metodologi Penelitian. Yogyakarta: Gadjah Mada University.

Surakhmad, Winarno. 2004. Pengantar Penelitian Ilmiah. Bandung: Tarsito.

Tim Puspendik. 2008. Tes Tertulis. Jakarta Pusat :Pusat Penilaian Pendidikan Badan Penelitian dan Pengembangan Departemen Pendidikan Nasional.

Uno, Hamzah. 2009. Perencanaan Pembelajaran. Jakarta: Bumi Aksara. 